\title{
Influence of strategic planning on product marketing and health service orientation of community pharmacies-A national survey in Finland
}

\author{
Jokinen, Lenita
}

2019-05

Jokinen , L , Puumalainen , I \& Airaksinen , M 2019, ' Influence of strategic planning on product marketing and health service orientation of community pharmacies-A national survey in Finland ', Health Policy, vol. 123 , no. 5 , pp. 462-467 . https://doi.org/10.1016/j.healthpol.2019.02.006

http://hdl.handle.net/10138/314262

https://doi.org/10.1016/j.healthpol.2019.02.006

cc_by_nc_nd

acceptedVersion

Downloaded from Helda, University of Helsinki institutional repository.

This is an electronic reprint of the original article.

This reprint may differ from the original in pagination and typographic detail.

Please cite the original version. 
- revised manuscript: HEAP-D-17-00144

\title{
Influence of strategic planning on product marketing and health service orientation of community pharmacies - A national survey in Finland
}

\author{
Authors: \\ Lenita Jokinen, MSc (Pharm), PD, Runosmäki Pharmacy, Turku, Finland; PhD student, Clinical \\ Pharmacy Group, Division of Pharmacology and Pharmacotherapy, Faculty of Pharmacy, University \\ of Helsinki, Finland
}

Inka Puumalainen, PhD, MSc (Pharm), Director, University Pharmacy, Finland

Marja Airaksinen, Professor, PhD, MSc(Pharm), Clinical Pharmacy Group, Division of Pharmacology and Pharmacotherapy, Faculty of Pharmacy, University of Helsinki, Finland

Corresponding author with contact details: Lenita Jokinen, lenita.jokinen@gmail.com, Askelkuja 5, 21350 Ilmarinen, Finland.

Word counts for the abstract 219 and the manuscript 3015 (not including tables, figures and Appendix 1).

Funding: This study was supported in part by grants from the Association of Finnish Pharmacies. 


\section{Influence of strategic planning on product marketing and health service orientation of community pharmacies - A national survey in Finland}

Word counts for the abstract 219 and the manuscript 3015 (not including Tables and 1 Appendix).

\section{Abstract}

The aim of this study was to explore pharmacy owners' views on the strategic development of community pharmacies, particularly how strategic planning at the pharmacy level influences on product marketing and health service orientation of individual community pharmacies.

The study was carried out as a national cross-sectional e-mail survey sent to all privately-owned Finnish community pharmacies ( $n=581$ ) in March 2013 (response rate 34\%, n=198). The pharmacy owners were asked about their strategy, product marketing and health services activities at the time of the survey and what they regarded as potential strategic developments by 2020 .

Of the responding pharmacy owners $(n=198), 63 \%$ reported their pharmacy had a strategy. The strategy was more common if the pharmacy owner had $>10$ years of experience as a pharmacy owner, the pharmacy had a high prescription volume (annually $>100000$ prescriptions) and sales volume (annual turnover $>5$ million euros). Pharmacy owners' strategic vision by 2020 concerning health service orientation was the same regardless of having a strategy. Having a strategy was associated with the following variables indicating active product marketing orientation: the pharmacy had a person responsible for marketing campaigns and monitoring their success, and the pharmacy actively invested in add-on sales. Economic uncertainty of community pharmacies is an unresolved issue driving them towards active product marketing even they strategically prioritized health service orientation. 
Keywords: community pharmacies, health services, strategy, marketing, healthcare

\section{Introduction}

Marketplace for community pharmacies is undergoing remarkable changes in Finland. This is due to the ongoing major societal changes that reflect in the social and health service system which is also under reform. ${ }^{1-3}$ Finland has a privately-owned community pharmacy system that has been proactively developed by the profession and its stakeholders. ${ }^{4-7}$ The community pharmacy system is highly regulated to ensure its commitment to the nation's health policy goals. ${ }^{6,8-10}$ Pharmacies, owned by pharmacists and each of them employing an average of 6 staff pharmacists, have such potential in pharmaceutical expertise that it could be exploited in healthcare more efficiently. ${ }^{2,3,11}$ International studies indicate that consumers are not aware of the professional services pharmacies offer but see them merely as traditional medicine distributors. ${ }^{12-15}$ Recent changes in social and healthcare systems in Finland have enabled pharmacists to extend their service provision in healthcare. ${ }^{3,16}$ Experiences from other countries indicate that societal support to community pharmacies is essential to carry out this kind of changes. ${ }^{10,12-13,17-18}$

In Finland, the government has implemented several actions to reduce prescription medicine costs, such as generic substitution in 2003 , followed by the reference price system in 2009 to control the prices of prescription medications. ${ }^{19} \mathrm{~A}$ decrease in the margins of prescription medicines sales has affected the economic structure and viability of Finnish community pharmacies. ${ }^{19-20}$ In order to support the economic stability, pharmacies have been extending their product portfolio to free trade goods. This has forced pharmacy owners to make more careful long-term strategic planning on their business orientation and service provision in order to assure acceptable profit level. As a consequence, it is possible to distinguish three different strategic orientations in the current community pharmacy business planning in Finland: 1) specialty storeoriented pharmacy, 2) dispensing and medicine distribution oriented pharmacy and 3) healthcare oriented pharmacy. Part of pharmacy owners have kept their strategic focus on traditional dispensing and medicine distribution (i.e., dispensing oriented pharmacies). There has been quite a strong movement towards extending the sales of free trade goods, particularly cosmetics, herbal products, and other self-care products for maintaining health and wellbeing. Strategically, those pharmacies can be considered as specialty store-oriented pharmacies. The most controversial within the pharmacy profession has been the clinical role orientation and the strategic shift 
towards health service provision, e.g., conducting medication reviews and providing automated dose dispensing service for home care and nursing home clients. However, examples from some countries, such as the USA, Australia, and Great Britain, indicate that pharmacies can strengthen their financial, professional and societal role by specializing in health services supporting rational and safe medication use. ${ }^{12-13,21}$

In Finland, the current Medicines Policy 2020 document by the Ministry of Social Affairs and Health provides a clear strategic signal to integrate community pharmacies into social welfare and healthcare system. ${ }^{6}$ However, little is known about pharmacy owners' commitment to these medicines policy goals and how their strategic planning supports implementation of the policy. The aim of this study was to explore pharmacy owners' views on the strategic development of community pharmacies, particularly how strategic planning at the pharmacy level influences product marketing and health service orientation of individual community pharmacies.

\section{Materials and Methods}

\section{Study design}

This study was conducted in March 2013 as a national cross-sectional e-mail survey to all members of the Association of Finnish Pharmacies ( $n=581$ ), covering the vast majority of approximately 600 private pharmacy owners in Finland.

\section{Development of the survey instrument}

The content of the survey instrument was derived from the key issues focusing on the community pharmacy system in recent official policy documents, such as Medicines Policy 2020 by the Ministry of Social Affairs and Health. ${ }^{6,16}$ Also the strategies and professional service development programs of the Association of Finnish Pharmacies and other key stakeholders were taken into account. ${ }^{22}$ An e-mail survey instrument containing structured and open-ended questions was divided into five sections: 1) characteristics of the pharmacy owner and his or her pharmacy business, 2) characteristics of the pharmacy's strategic development, 3) business and economy, 4) marketing efforts taken and those coordinated through a possible membership in a marketing chain of individual community pharmacies, and 5) range of services provided in the pharmacy at 
the time of the survey and pharmacy owner's opinions on investing in health care oriented service development by 2020. Most of the questions were structured applying the 5-point Likert-scale format and were accompanied by an open question.

The method and the survey instrument were piloted in September 2012 with a regional group of pharmacy owners in western Finland $(n=145) .{ }^{23}$ The response rate for the pilot survey was $35 \%$ $(n=51)$. Some of the questions were modified after the pilot study, but the essence remained the same. Prior to the current survey, the content of the survey instrument was discussed with national community pharmacy experts to gain their feedback and suggestions for modifications.

\section{Data collection and analysis}

The national survey to pharmacy owners was carried out by an electronic Webropol data collection program in March 2013. The pharmacy owners' e-mail addresses were obtained from the Association of Finnish Pharmacies. One reminder message by e-mail was sent after one week of sending the original survey.

Responses were analyzed using the SPSS program. The results are presented as frequencies and percentages. The statistical significance in the bivariate analyses was tested by Chi Square test ( $p$ value of $<0.05$ was considered statistically significant).

For the analysis, the respondents were divided into two groups according to whether or not they had a strategy. The bivariate analysis was applied to count the association between 1) strategy work and variables indicating active product marketing orientation and 2) strategy work and variables indicating health service orientations. Eight independent variables were used to operationalize typical product marketing and campaigning activities in Finnish community pharmacies (Figure 1) and 13 variables for operationalizing provision of health services at the time of the survey (Figure 2). Reliability analysis (Chronbach's Alpha) was applied to calculate the internal consistency of the variables in both strategic approached to indicate survey instrument's construct validity.

Background variables used in this study included work experience as a pharmacy owner, the pharmacy owner's gender, pharmacy's location by province and type of area (e.g., countryside, city center), annual prescription volume and turnover, whether the pharmacy had 1) limited 
liability company, 2) subsidiary, 3) online pharmacy, 4) service point, and 5) whether the pharmacy was a member of a pharmacy chain (marketing chain of individual community pharmacies, actual pharmacy chains are not allowed in Finland).

\section{Results}

The response rate was $34 \%(n=198)$. The majority (42\%) of the respondents were experienced pharmacy owners for over ten years (Table 1). The majority (72\%) of the respondents were women, which is in line with the gender distribution of all pharmacy owners in Finland. ${ }^{24}$ Respondents represented the size distribution of pharmacies based on their annual prescription volume quite well. ${ }^{24}$ Of the respondents, $40 \%$ planned to apply for a new pharmacy license and resign from their current one or retire within a three-year period after the time of the survey. Of the respondents, $45 \%$ operated their pharmacy in a rural community.

Table 1. Characteristics of the responding pharmacy owners $(n=198)$ and their pharmacy outlets compared to all privately-owned community pharmacies in Finland at the point of the survey $(n=592)$ (\% of the respondents).

Almost two-thirds $(63 \%, n=123)$ of the pharmacy owners reported that their pharmacy had a strategy. Having a strategy was influenced by the length of the career as a pharmacy owner, pharmacy's annual prescription volume and turnover, and existence of a limited liability company (Table 2). The tendency was that pharmacy owners having more than ten years of experience were more likely to have a strategy for their pharmacy. The strategy was more common in pharmacies with high prescription volume (>100 000 dispensed prescriptions a year) and turnover ( $>5$ million euros a year).

Table 2. Having a strategy in community pharmacies according to characteristics of pharmacy owners and their pharmacy outlets (the proportion of those respondents who reported having a 
strategy for their pharmacy, $n=123)$. n.s.: not significant.

At the point of the survey in 2013, automated dose dispensing was the most common healthoriented service provided, with $77 \%$ of the responding pharmacies providing it (Appendix 1 ). The range of pharmacies offering other health-oriented services varied between $6 \%-37 \%$, health-check service being the least provided ( $8 \%$ of all responding pharmacies). A more detailed description of the health-related services included in this study is given in Appendix 1.

The internal consistency of both sets of variables indicating pharmacy's product marketing orientation and health service orientation was acceptable (Cronbach's Alpha 0.699 for the 8 variables related to product marketing orientation and 0.836 for the 13 variables indicating pharmacy's health service orientation). Less than a third (29\%) of the responding pharmacy owners reported that concentration of product sales was an important part of their pharmacy's strategy (Figure 1). Concerning product marketing orientation, pharmacy owners reported most commonly having an employee responsible for creating product marketing campaigns ( $81 \%$ of the respondents) and monitoring the success of such campaigns (74\%) (Figure 1). About the same proportion of the pharmacy owners (75\%) reported extending their product sales towards nonpharmaceutical free trade brands exclusively available in pharmacies. Having a strategy influenced the following variables indicating active product marketing orientation: the pharmacy had an employee responsible for product marketing campaigns and monitoring their success, and the pharmacy actively invested in add-on sales (Figure 1).

Figure 1. Association between having a strategy and pharmacy's active product marketing orientation (\% of the responding pharmacy owners, $n=198$ ). The internal consistency of the variables ( $n=8$ ) was 0.699 (Chronbach's Alpha). n.s.: not significant.

Having a strategy was not associated with pharmacy owners' opinions on health service orientation, except that those having a strategy were more interested in providing services promoting medication safety, such as comprehensive medication reviews (Figure 2). The respondents most agreed with the items related to willingness to create competence needed in 
providing specialized health services, such as comprehensive medication reviews, if there were national standards and funding for these services. The least agreed on were the items indicating that online pharmacy services would extend to services provided by almost all pharmacies, and that pharmacy service points with the limited assortment and services would assure access to medicines in sparsely populated areas.

Figure 2. Association between having a strategy and health service orientation of community pharmacies. The internal consistency of the variables $(n=13)$ was 0.836 (Chronbach's Alpha). n.s.: not significant

\section{Discussion}

Pharmacy owners' strategic vision by 2020 concerning health service orientation was the same regardless of having a strategy for their business or not, but the active product marketing orientation was influenced by having a strategy. By 2020, approximately half of the responding pharmacy owners indicated they are ready to invest in competencies needed in specialized health services, such as comprehensive medication reviews, if these services had standardized procedures and if they were funded as part of health services from the public health budget.

The tendency was that the pharmacy owners having more than 10 years of experience as an owner were more likely than others to have a strategy for their pharmacy. The strategy was more common in pharmacies with a high prescription volume (>100 000 dispensed prescriptions a year), a turnover higher that 5 million euros a year and in pharmacies having a limited liability company. In this study, the reasons and motives for strategic planning and having a strategy were not assessed. Usually in Finland the pharmacist's career as a pharmacy owner starts in a small pharmacy in a countryside community or in a small town. Pharmacy owners may not consider strategy necessary in these business environments without rivals. Also, the dynamics of managing a small rural pharmacy with few workers is different from managing a larger pharmacy employing up to 30 pharmacists and 8 technicians. A larger pharmacy with more resources provides more opportunities for professional and commercial business development, but requires more attention to organizing the work, allocating the resources, controlling finances and strategically planning the 
business and services.

According to this study, having a strategy positively influenced pharmacy owners' willingness to invest in provision of some health oriented services requiring special expertise or even accreditation, such as medication reviews, medication consultations and services for special patient groups. At the same time, willingness to provide many other health services was not influenced by strategy work, e.g., provision of automated dose dispensing, health-check service and other health screenings, such as measuring blood pressure, inhaler technique checks and smoking cessation services. This may indicate that pharmacy owners need a strong commitment to providing professional services in order to make long-term investments in such services that require new competencies of the staff and closer collaboration with local healthcare providers, but the future demand and income is uncertain. On one hand, implementing comprehensive medication review services requires specially trained staff. ${ }^{25-26}$ On the other hand, such services as automated dose dispensing, health-checks and other health screenings are easier to implement without additional resources and long-term investments.

Previous evidence from other countries with more advanced clinical service provision in community pharmacies demonstrate that the implementation of novel professional services is a long process that requires strategic commitment and resource allocation. 13,15,17,27 Finnish community pharmacies have particularly invested in improving patient counseling services since the 1990s with the support of professional bodies, authorities, pharmacy schools and continuing education organizations. ${ }^{4}$ Even with extensive, long-term, coordinated efforts the change has been slow. The commitment of pharmacy owners to shared national health and medication policy goals is crucial. In Finland, the polarization of pharmacies to those willing to extend their operations towards professional health-oriented services and those willing to base their business on traditional dispensing and active product sales is evident. ${ }^{4}$

A visibly larger proportion of pharmacies having a strategy seem to be heading towards active product marketing and extending their product assortment beyond pharmaceutical products to free trade brands exclusively available in pharmacies. Those pharmacies having a strategy also favored the promotion of add-on sales. Thus, community pharmacies have begun to focus on active product sales to ensure their profitability. This trend towards a more business-oriented pharmacy practice became evident after the government launched the reference price system in 
Finland in 2009 in order to cut the increase in prescription drug costs. Since then, authorities have made regular follow-ups on the finances of community pharmacies. ${ }^{19-20,28}$ The economic analyses have concluded that pharmacies continue to have solid economy and they are still earning profitable business. Even though the reference price system has cut the prices of prescription medications reimbursed through the public social insurance system covering the whole population, new reimbursement cuts have been needed during the last years. This has increased pharmacy owners' willingness and tendency to compensate for reduced prescription drug profits by active product marketing and extending the assortment to cosmetics, food supplements and other health and wellbeing products. Differences between pharmacies in terms of operating profit has grown within different turnover groups during the recent years, and particularly, the operations of the smallest pharmacies require precise financial planning. ${ }^{28}$

Our study indicates that product sales orientation and health services orientation of the pharmacy are not separated, but complement each other. Thus, the same pharmacy can simultaneously emphasize both active product marketing and health-oriented services in their strategy. A more detailed content of each pharmacy's strategy was not investigated in this study, and neither was the pharmacy owners' motives for their strategic decisions. Previous evidence on the strategic planning at the individual pharmacy level was scarce, which is surprising if we think about how crucial it is for community pharmacies' finances and their societal function. Further research is needed to understand the influence of strategic planning on pharmacies' service provision and quality, as well as efficiency and cost management. Future research should also identify factors associated to the health care orientation and active product marketing orientation of community pharmacies. Likewise, the content of the strategy and its influence on performance should be explored more in detail.

The response rate of this national survey was rather low (34\%). These results can be considered as indicative since the nationwide number of responses was 198 out of 581 pharmacy owners. The geographic location and prescription volume of the respondents' pharmacies accurately represent all pharmacies in Finland. The response rate of this study can be considered as a typical response rate for email surveys targeted to community pharmacists and pharmacy owners. ${ }^{29}$ However, it is possible that pharmacy owners interested in strategy work and service development have been more active to respond than others. It is difficult to compare the results of this survey with international studies as pharmacy systems and their operational contexts vary by country. In 
contrast, few similar strategic surveys have been previously published.

Since the work was carried out in 2013 , the political focus has shifted towards health services orientation along with the ongoing social and health services reform. As part of the current government program, the Ministry of Social Affairs and Health established a rational pharmacotherapy action plan 2018-2022. ${ }^{3}$ According to the action plan, community pharmacy services are expected to be better integrated into health care system to enhance coordination of medication management. Pharmacy owners' association has been proactively involved in policy making and supports the plans towards health care service orientation of community pharmacies. However, the economic uncertainty of community pharmacies is still an unresolved issue. ${ }^{28}$

\section{Conclusions}

Private community pharmacy owners' strategic vision by 2020 concerning health service orientation was the same regardless of having a strategy or not, but the product marketing orientation was influenced by having a strategy. Of the characteristics of the pharmacy owner and the pharmacy, only the owner's career length being longer than 10 years, pharmacy being located in the city or commercial center and the annual prescription volume being more than 100000 were positively associated to strategy work.

\section{Acknowledgements}

The authors thank Ms. Claudia Martin Diaz, PharmD Candidate, College of Pharmacy, University of Florida, USA, for proofreading the manuscript.

This study was supported by a grant from the Association of Finnish Pharmacies.

\section{References}

1. Government Reform Packages. Regional Government, Health and Social Services Reform. https://alueuudistus.fi/en/general-information-reform. Accessed January 6, 2019.

2. Prime Minister's Office. Finland, a land of solutions. Strategic Programme of Prime 
Minister Juha Sipilä's Government. Government Publications https://valtioneuvosto.fi/documents/10184/1427398/Ratkaisujen+Suomi_EN_YHDISTETTY _netti.pdf. Accessed January 6, 2019.

3. Ministry of Social Affairs and Health. Rational Pharmacotherapy Action Plan 2018-2022. Final Report. Reports and Memorandums 19/2018. http://julkaisut.valtioneuvosto.fi/handle/10024/160824. Accessed January 6, 2019.

4. Puumalainen I. Development of instruments to measure the quality of patient counselling. Doctoral dissertation. Kuopio University Publications A. Pharmaceutical Sciences 83. University of Kuopio, 2005. http://urn.fi/URN:ISBN:951-27-0053-0

5. Mossialos E. Srivastava D. Pharmaceutical policies in Finland: Challenges and opportunities. Ministry of Social Affairs and Health (Finland) and European Observatory on Health Systems and Policies. Copenhagen: World Health Organization, 2008.

6. Ministry of Social Affairs and Health. Medicines Policy 2020. Towards Efficient, Safe, Rational and Cost-effective Use of Medicines - Finland. Publications of the Ministry of Social Affairs and Health 2011:10. http://apps.who.int/medicinedocs/documents/s19762en/s19762en.pdf. Accessed January 6, 2019.

7. The Association of Finnish Pharmacies. Annual Report 2017. https://www.apteekkariliitto.fi/media/3-apteekkariliitto.fi/englanti/annualreviews/annual_report_2017.pdf. Accessed January 6, 2019.

8. Act on Medicines 395/1987.

9. Väänänen M. Community Pharmacies and the Needs of Mobile EU Citizens - A study on Finns living in Spain. Doctoral dissertation. University of Helsinki, 2008. http://urn.fi/URN:ISBN:978-952-10-4712-1. Accessed December 13, 2016.

10. Mossialos E, Courtin E, Naci H, Benrimoj S, Bouvy M, Farris K, Noyce P, Sketris I. From "retailers" to health care providers: Transforming the role of community pharmacists in chronic disease management. Health Policy. May;119(5):628-39, 2015.

11. Ministry of Social Affairs and Health. Apteekkitoiminnan ja muun lääkehuollon kehittäminen. Final Report. Reports and Memorandums 2015:4, [in Finnish] Helsinki 2015.

12. Roberts A, Benrimoj S, Chen T, Williams K, Hopp T, Aslani P. Understanding practice change in community pharmacy: a qualitative study in Australia. Res Social Adm Pharm 1(4):546$564,2005$.

13. Stubbings J, Nutescu E, Durley SF, Bauman JL. Payment for Clinical Pharmacy Services Revisited. Pharmacotherapy 31(1):1-8, 2011.

14. Smith M, Cannon-Brel M L, Spiggle S. Consumer, physician, and payer perspectives on primary care medication management services with a shared resource pharmacists' network. Res Social Adm Pharm 10(3):539-553, 2014.

15. Schommer J, Yusuf A, Hadsall R. Market dynamics of community pharmacies in Minnesota, US from 1992 through 2012. Res Social Adm Pharm 10(1):217-231, 2014.

16. Ministry of Social Affairs and Health. Avohuollon apteekkitoiminnan kehittämistarpeet. Sosiaali- ja terveysministeriön selvityksiä 2011:16, [in Finnish]. Helsinki Finland 2011.

17. Benrimoj SI, Frommer MS. Community pharmacy in Australia. Australian Health Review 28(2):238-246, 2004. 
18. Makowsky M, Guirguis L, Hughes C, Sadowski C, Yuksel N. Factors influencing pharmacists' adoption of prescribing: qualitative application of the diffusion of innovations theory. Implementation Science 8(1): 109-120, 2013.

19. Mäntylä A, Kiviniemi V, Happonen P. Analysis of pharmacies' financial statements for 2009-2012. Finnish Medicines Agency. Serial Publication Fimea Develops, Assesses and Informs 5/2013.

20. Mäntylä A, Kokki E, Kiviniemi V, Happonen P. Analysis of pharmacies' financial statements for 2008-2011. Finnish Medicines Agency. Fimea Develops, Assesses and Informs Publication Series 5/2012.

21. Singleton J, Nissen L. Future-proofing the pharmacy profession in a hypercompetitive market. Res Social Adm Pharm 10(2):459-468, 2014.

22. Association of Finnish Pharmacies. The strategy and strategy goals 2012-2020. [in Finnish] Helsinki 2011.

23. Jokinen L. Apteekkitoiminnan kehittäminen muuttuvassa toimintaympäristössä: apteekkareiden näkemyksiä. Professional development project work. [in Finnish]. University of Helsinki Centre for Continuing Education, 2012.

24. The Association of Finnish Pharmacies. Unpublished statistics 2012.

25. Leikola S. Development and Application of Comprehensive Medication Review Procedure to Community-Dwelling Elderly. Doctoral dissertation. University of Helsinki, 2012. http://urn.fi/URN:ISBN:978-952-10-7698-5. Accessed December 13, 2016.

26. Bulajeva A, Labberton L, Leikola S, Pohjanoksa-Mäntylä M, Geurts MM, de Gier JJ, Airaksinen M. Medication review practices in European countries. Res Social Adm Pharm 10(5):731-40, 2014.

27. Moullin JC, Sabater-Hernandez D, Benrimoj SI. Qualitative study on the implementation of professional pharmacy services in Australian community pharmacies using framework analysis. BMC Health Serv Res 16:439, 2016.

28. Reinikainen L, Hyvärinen A, Happonen P. Analysis of pharmacies' financial statements for 2013-2016. Finnish Medicines Agency Fimea. Serial Publication Fimea Develops, Assesses and Informs 5/2018.

29. Westerling A. Information Technology Development Needs in Community Pharmacies: A Strategic Approach. Doctoral dissertation. University of Helsinki 2011. http://urn.fi/URN:ISBN:978-952-10-7222-2. Accessed December 13, 2016.

30. Sinnemäki J, Sihvo S, Isojärvi J, Blom M, Airaksinen M, Mäntylä A. Automated dose dispensing service for primary healthcare patients: a systematic review. Systematic Reviews 2:1, 2013.

31. Kurko T. Deregulation of Nicotine Replacement Therapy Products in Finland: Reasons for Pharmaceutical Policy Changes and Reflections on Smoking Cessation Practices. Doctoral dissertation, University of Helsinki 2015. http://urn.fi/URN:ISBN:978-951-51-1223-1. Accessed January 13, 2019. 
Appendix 1. Description of health-related services available in Finnish community pharmacies (or part of the pharmacies) at the point of the survey in 2013

\begin{tabular}{|c|c|c|}
\hline Service & Description of the service & $\begin{array}{l}\text { Developer and year of } \\
\text { implementation }\end{array}$ \\
\hline $\begin{array}{l}\text { Automated dose dispensing } \\
\text { (ADD) }\end{array}$ & $\begin{array}{l}\text { A service in which a pharmacy } \\
\text { dispenses client's regularly used } \\
\text { medicines (two weeks at a } \\
\text { time) as machine-packed unit } \\
\text { doses for each time of } \\
\text { administration. ADD is } \\
\text { recommended to Include } \\
\text { medication review (16-Ministry } \\
\text { of Social Affairs and health } \\
2013,30 \text {-Sinnemäki at al. 2013) }\end{array}$ & $\begin{array}{l}\text { Association of Finnish } \\
\text { Pharmacies, } 2002\end{array}$ \\
\hline $\begin{array}{l}\text { Comprehensive medication } \\
\text { review (CMR) }\end{array}$ & $\begin{array}{l}\text { The procedure is for a } \\
\text { comprehensive } \\
\text { clinical review of all used } \\
\text { medications. It is based on } \\
\text { collaboration between } \\
\text { pharmacists and other health } \\
\text { care professionals, particularly } \\
\text { physicians, and it includes } \\
\text { access to clinical patient data, a } \\
\text { home visit with a patient } \\
\text { interview, written case report } \\
\text { with DRPs and recommended } \\
\text { actions to solve them, case } \\
\text { conference with the physician } \\
\text { and a follow up of } \\
\text { implementation of the } \\
\text { recommended changes in the } \\
\text { medication. Requires } \\
\text { accreditation training for } \\
\text { pharmacists (16-Ministry of } \\
\text { Social Affairs and health } 2011 \text {, } \\
\text { 25-Leikola 2016) }\end{array}$ & $\begin{array}{l}\text { National coordination group } \\
\text { concerning new professional } \\
\text { community pharmacy services, } \\
2005\end{array}$ \\
\hline
\end{tabular}




\begin{tabular}{|c|c|c|}
\hline Smoking cessation & $\begin{array}{l}\text { A service based on individual } \\
\text { support and counseling that } \\
\text { aims to quit smoking using NRT } \\
\text { products (31-Kurko at al. 2015) }\end{array}$ & $\begin{array}{l}\text { Association of Finnish } \\
\text { Pharmacies, } 2005\end{array}$ \\
\hline Asthma/diabetes service & $\begin{array}{l}\text { Enhanced medication } \\
\text { counseling service for specific } \\
\text { patient groups. Requires } \\
\text { accreditation training for } \\
\text { pharmacists to perform. }\end{array}$ & $\begin{array}{l}\text { Association of Finnish } \\
\text { Pharmacies, } 2009\end{array}$ \\
\hline Medication consultation & $\begin{array}{l}\text { Consulting service to assist } \\
\text { social and health care units to } \\
\text { establish their plan for safe } \\
\text { medication practices. }\end{array}$ & $\begin{array}{l}\text { Association of Finnish } \\
\text { Pharmacies, } 2011\end{array}$ \\
\hline $\begin{array}{l}\text { Inhalation technique check-up } \\
\text { service for asthma and chronic } \\
\text { obstructive pulmonary } \\
\text { disease (COPD) patients }\end{array}$ & $\begin{array}{l}\text { The service is targeted to those } \\
\text { asthma and COPD patients who } \\
\text { may have problems with taking } \\
\text { their inhaled medication. } \\
\text { Another target group is children } \\
\text { and adolescents at the point of } \\
\text { starting to take responsibility } \\
\text { for their medication }\end{array}$ & $\begin{array}{l}\text { Association of Finnish } \\
\text { Pharmacies, } 2012\end{array}$ \\
\hline Health check & $\begin{array}{l}\text { A service for assessing client's } \\
\text { lifestyle and the most common } \\
\text { clinical measures for estimating } \\
\text { health risks, such as heart } \\
\text { attack, stroke and diabetes }\end{array}$ & $\begin{array}{l}\text { Association of Finnish } \\
\text { Pharmacies, } 2012\end{array}$ \\
\hline $\begin{array}{l}\text { Medication review/prescription } \\
\text { review }\end{array}$ & $\begin{array}{l}\text { A service for reviewing the } \\
\text { customer's medication list. } \\
\text { The purpose is to identify } \\
\text { duplicate medications, } \\
\text { inappropriate dosing and drug- } \\
\text { drug interactions (16-Ministry } \\
\text { of Social Affairs and health } \\
2011 \text { ) }\end{array}$ & $\begin{array}{l}\text { Association of Finnish } \\
\text { Pharmacies, } 2012\end{array}$ \\
\hline
\end{tabular}


Table 1. Characteristics of the responding pharmacy owners $(n=198)$ and their pharmacy outlets compared to all privately-owned community pharmacies in Finland at the point of the survey $(n=592)(\%$ of the respondents)

\begin{tabular}{|c|c|c|c|c|}
\hline \multirow[t]{2}{*}{ Variable } & \multicolumn{2}{|c|}{ Respondents ( $n=198$ ) } & \multicolumn{2}{|c|}{ Target population $(n=592)$} \\
\hline & $\%$ & $\mathrm{n}$ & $\%$ & $\mathrm{n}$ \\
\hline \multicolumn{5}{|c|}{$\begin{array}{l}\text { Work experience as a pharmacy } \\
\text { owner }\end{array}$} \\
\hline Less than 5 years & 36 & 69 & \multicolumn{2}{|c|}{ Not available } \\
\hline $5-10$ years & 23 & 44 & \multicolumn{2}{|c|}{ Not available } \\
\hline More than 10 years & 42 & 81 & \multicolumn{2}{|c|}{ Not available } \\
\hline \multicolumn{5}{|l|}{ Pharmacy owner's gender } \\
\hline Female & 72 & 143 & 73 & 432 \\
\hline Male & 28 & 54 & 27 & 160 \\
\hline \multicolumn{5}{|l|}{ Location by province } \\
\hline Southern Finland & 30 & 58 & \multicolumn{2}{|c|}{ Not available } \\
\hline Western Finland & 38 & 74 & \multicolumn{2}{|c|}{ Not available } \\
\hline Eastern Finland & 16 & 32 & \multicolumn{2}{|c|}{ Not available } \\
\hline Northern Finland & 16 & 32 & \multicolumn{2}{|c|}{ Not available } \\
\hline \multicolumn{5}{|l|}{ Business location } \\
\hline Countryside & 45 & 88 & \multicolumn{2}{|c|}{ Not available } \\
\hline City, center & 22 & 42 & \multicolumn{2}{|c|}{ Not available } \\
\hline City, suburb & 14 & 27 & \multicolumn{2}{|c|}{ Not available } \\
\hline City, commercial center & 19 & 38 & \multicolumn{2}{|c|}{ Not available } \\
\hline \multicolumn{5}{|l|}{ Annual prescription volume } \\
\hline Less than 40000 & 27 & 52 & 25 & 148 \\
\hline $40000-60000$ & 19 & 37 & 19 & 115 \\
\hline $60001-100000$ & 32 & 63 & 32 & 191 \\
\hline More than 100000 & 22 & 44 & 22 & 130 \\
\hline
\end{tabular}

${ }^{1}$ Source: Association of Finnish Pharmacies 2012. ${ }^{24}$ 
Table 2. Strategy work in community pharmacies according to characteristics of pharmacy owners and their pharmacy outlets (the proportion of those respondents who reported having a strategy for their pharmacy, $n=123$ ). n.s.: not significant.

\begin{tabular}{|c|c|c|c|}
\hline \multirow[t]{2}{*}{ Variable } & \multicolumn{2}{|c|}{ Strategy work } & \multirow[t]{2}{*}{ p-value } \\
\hline & $\%$ & $\mathrm{n}$ & \\
\hline Work experience as a pharmacy owner & & & $<0.001$ \\
\hline Less than 5 years & 43 & 30 & \\
\hline $5-10$ years & 65 & 28 & \\
\hline More than 10 years & 78 & 61 & \\
\hline Pharmacy owner's gender & & & n.s. \\
\hline Female & 63 & 87 & \\
\hline Male & 66 & 35 & \\
\hline Location by province & & & n.s. \\
\hline Southern Finland & 66 & 37 & \\
\hline Western Finland & 68 & 50 & \\
\hline Eastern Finland & 42 & 13 & \\
\hline Northern Finland & 69 & 22 & \\
\hline Location area & & & \\
\hline Countryside & 59 & 51 & n.s \\
\hline City, center & 68 & 28 & \\
\hline City, suburb & 58 & 15 & \\
\hline City, commercial center & 74 & 28 & \\
\hline Annual prescription volume & & & 0.007 \\
\hline Less than 40000 & 44 & 23 & \\
\hline $40000-60000$ & 69 & 24 & \\
\hline $60001-100000$ & 66 & 41 & \\
\hline More than 100000 & 77 & 33 & \\
\hline Turnover million $€$ & & & 0.008 \\
\hline Less than 0,7 & 44 & 19 & \\
\hline 0,7- 2,499 999 & 58 & 21 & \\
\hline 2,500 $000-3,399999$ & 71 & 22 & \\
\hline 3,400 $000-4,999999$ & 67 & 32 & \\
\hline 5,000000 or more & 84 & 26 & \\
\hline Does the pharmacy have & & & \\
\hline Limited liability company & 77 & 51 & 0.003 \\
\hline
\end{tabular}


Subsidiary (max 3 allowed)

Online pharmacy

Service point (limited assortment)

Member of a marketing chain

\begin{tabular}{l|l|l|}
54 & 27 & n.s. \\
81 & 22 & n.s. \\
65 & 11 & n.s. \\
\hline 62 & 67 & n.s. \\
\hline
\end{tabular}


The pharmacy has a person responsible for campaigns or product marketing $(p<0.001)$

The pharmacy monitors the success of campaigns

$$
(p<0.001)
$$

The pharmacy favors free trade brands that are sold only in pharmacies ( $p=n . s$.)

It is necessary for pharmacies to expand product portfolio to ensure the economy ( $p=n . s$.)

The pharmacy is actively investing in additional sales $(p=0.005)$

Product marketing efforts will increase in pharmacies ( $p=n . s$.

Pharmacy chains have growing importance in the future ( $p=n . s$.

Focus on product marketing is an important part of the strategy ( $p=n . s$.

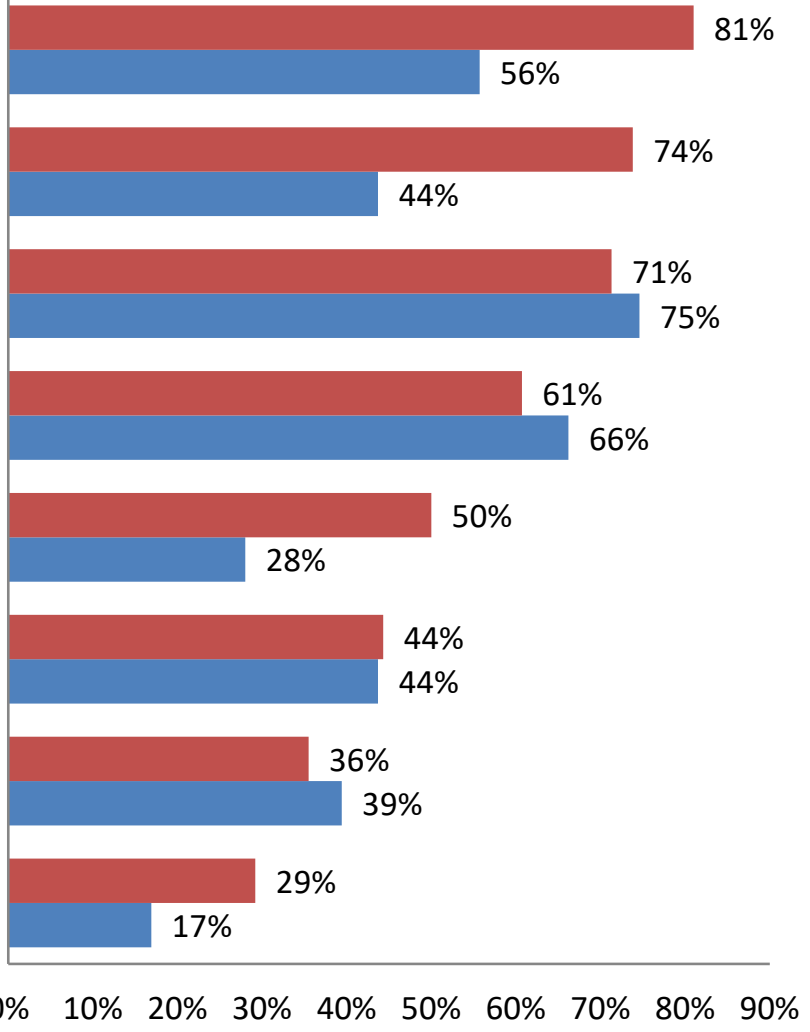

- Pharmacies having a strategy $(n=123)$
- Pharmacies not having a strategy $(n=75)$

Figure 1. Association between strategy work and pharmacy's product marketing orientation (\% of the responding pharmacy owners, $n=198)$. The internal consistency of the variables $(n=8)$ was 0.699 (Chronbach's Alpha). n.s.: not significant 
Pharmacies are willing to increase specific competencies required for specific services (e.g., comprehensive medication reviews) ( $p=n . s$.

Pharmacies should commercialize services ( $p=n . s$.

Development of new services is important for pharmacy business ( $p=n . s$.)

My pharmacy is interested in new services such as inhalation check for asthma patiens ( $p=n . s$.)

My pharmacy is interested in developing online pharmacy services ( $p=n . s$.)

Pharmacies could become substitutes for primary health care units in areas with no public health centers ( $p=n . s$.

Comprehensive medication review services will be an important part of future activities of community pharmacies ( $p=n . s$.

My pharmacy is interested in new paid services that improve medication safety $(p=0.034)$

Community pharmacies could also provide vaccination services ( $p=n . s$.

My pharmacy is interested in providing paid services such as telephone counselling by the pharmacist $(p=n . s$.)

Future pharmacy activities will orient more towards health promotion services ( $p=n . s$.)

The online pharmacy services will extend to operations of nearly every pharmacy $(p=n . s$.

Pharmacy service points will assure access to medicines in sparsely populated areas in the future ( $p=n . s$.

Pharmacies having a strategy $(n=123)$

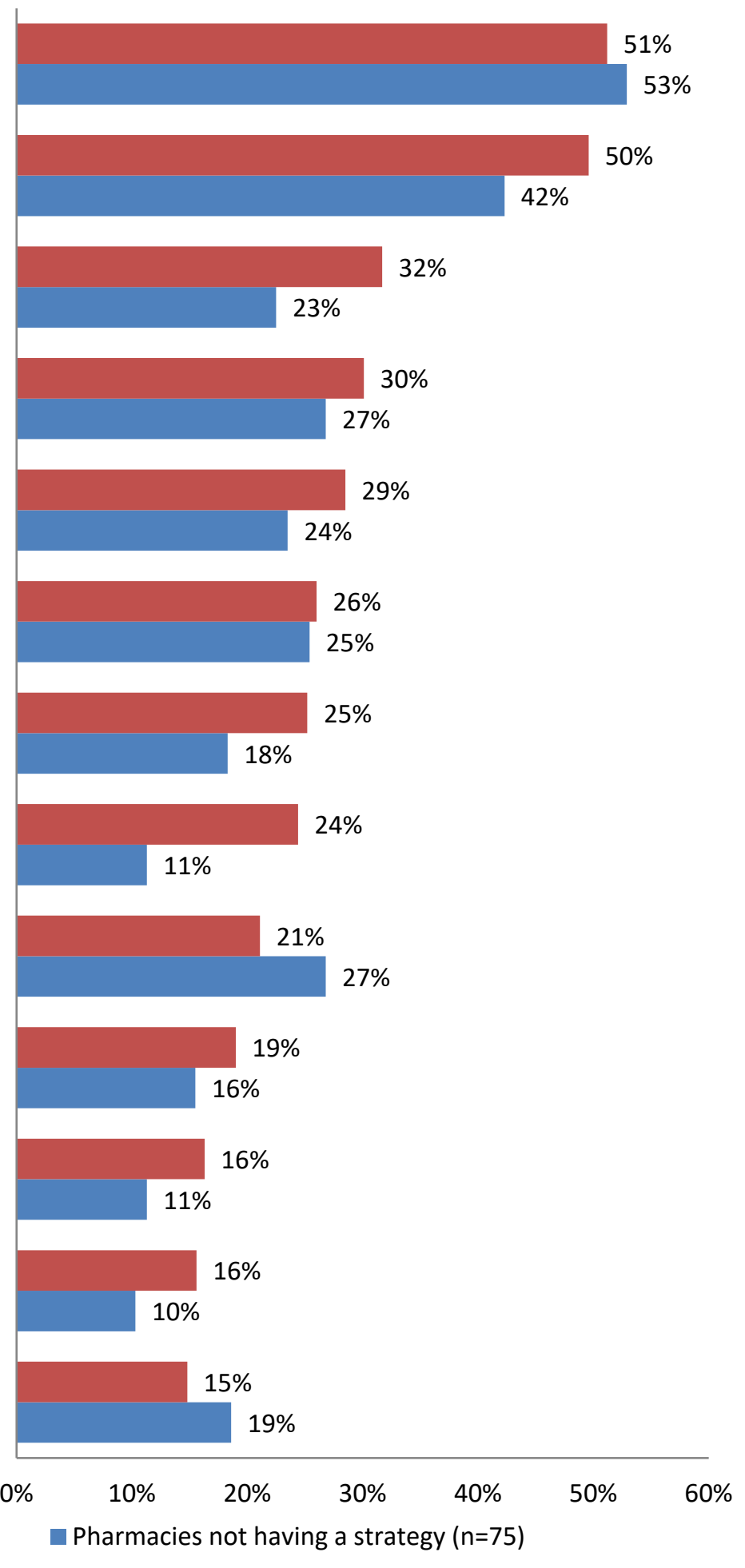


Figure 2. Association between having strategy and health service orientation of community pharmacies. The internal consistency of the variables $(n=13)$ was 0.836 (Chronbach's Alpha). n.s.: not significant 